\title{
DLL4 wt Allele
}

National Cancer Institute

\section{Source}

National Cancer Institute. DLL4 wt Allele. NCI Thesaurus. Code C90318.

Human DLL4 wild-type allele is located in the vicinity of $15 q 14$ and is approximately $10 \mathrm{~kb}$ in length. This allele, which encodes Delta-like protein 4, plays a role in the modulation of notch signaling and may play a role in neovascularization. 